\title{
PENERAPAN STRATEGI PEMBELAJARAN THINK PAIR SHAREUNTUK MENINGKATKAN KEMAMPUAN MEMBACA INTENSIF SISWA
}

\author{
Nyoman Murda1,*, Putu Diah Purwanti² \\ 1 Jurusan Pendidikan Guru Sekolah Dasar. Universitas Pendidikan Ganesha, Indonesia \\ ${ }^{2} J u r u s a n$ Pendidikan Guru Sekolah Dasar. Universitas Pendidikan Ganesha, Indonesia
}

\section{Abstrak}

Penelitian ini bertujuan untuk mengetahui peningkatan kemampuan membaca intensif siswa kelas IV Semester II tahun ajaran 2010/2011 pada SD No. 4 Penarukan setelah diterapkannya strategi pembelajaran Think Pair Share.Jenis penelitian ini adalah penelitian tindakan kelas yang dilaksanakan dalam dua siklus. Setiap siklus terdiri dari tahap perencanaan, pelaksanaan tindakan, observasi dan evaluasi, serta refleksi. Subyek penelitian ini adalah siswa kelas IV Semester II SD No. 4 Penarukan Tahun Pelajaran 2010/2011 sebanyak 28 orang. Objek penelitian ini adalah kemampuan membaca intensif siswa kelas IV Semester II SD No. 4 Penarukan. Data kemampuan membaca intensif siswa dikumpulkan melalui tes berbentuk objektif yang dianalisis secara deskriptif kuantitatif.Hasil penelitian menunjukkan bahwa penerapan strategi pembelajaran Think Pair Share dapat meningkatkan kemampuan membaca intensif siswa. Pada refleksi awal, rata-rata persentase kemampuan membaca intensif siswa hanya mencapai 59,29\% dengan kategori kurang, setelah siklus I rata-rata persentase kemampuan membaca intensif siswa siswa mengalami peningkatan mencapai $64,82 \%$ dengan kategori kurang dan pada akhir siklus II ratarata hasil kemampuan membaca intensif siswa mencapai $77,14 \%$ dengan kategori cukup
\end{abstract}

Keywords:

Strategi pembelajaran

Think-Pair-Share,

kemampuan membaca

intensif.

\section{Pendahuluan}

Fungsi bahasa sebagai sarana komunikasi bagi manusia, baik komunikasi lisan maupun tulis. Bahasa merupakan aspek vital yang harus dikuasai seseorang dalam melakukan komunikasi sehari-hari. Dalam dunia pendidikan bahasa memiliki peran sentral dalam perkembangan intelektual, sosial, emosional peserta didik, juga merupakan aspek penunjang dalam keberhasilan mempelajari bidang studi (Departemen Pendidikan Nasional, 2006).

Dalam mata pelajaran Bahasa Indonesia di sekolah dasar mencakup komponen keterampilan berbahasa dan ketrampilan bersastra, yang meliputi empat aspek keterampilan berbahasa yaitu menyimak, berbicara, membaca, dan menulis (Departemen Pendidikan Nasional, 2006). Keempat aspek terampilan berbahasa ini saling terkaiat antara satu dengan yang lainnya. Keterampilan menyimak dan berbicara merupakan keterampilan awal yang dimiliki oleh setiap anak yang diperoleh dari pendidikan non formal di dalam keluarga dan lingkungan tempat di mana dia tinggal. Berbeda halnya dengan keterampilan membaca dan menulis yang pada umumnya baru berkembang dan dipelajari anak ketika ia menempuh pendidikan formal di sekolah.

Dari keempat keterampilan berbahasa tersebut keterampilan membaca secara oprasional memiliki peranan yang sangat penting dalam memahami isi bacaan. Dalam pembelajaran membaca di sekolah siswa dituntut untuk memahami isi bacaan, seperti menjawab pertanyaan yang berkaitan dengan isi bacaan, menemukan gagasan utama dalam bacaan, dan merangkum isi bacaan. Kemampuan membaca dan memahami isi bacaan sangat penting dikuasi siswa, karena kemampuan ini dibutuhkan untuk menyelesaikan tugas-tugas yang diberikan oleh guru, seperti menjawab pertanyaan, meringkas serta untuk menambah pengetahuan tentang pelajaran yang diajarkan di sekolah. Sukses dalam membaca 
sangat penting bagi siswa dalam rangka mengembangkan kemampuan akademik, keahlian, dan kecerdasan (Carnine dalam Sudiana, 2007). Sementara itu Yunus, (dalam Sudiana, 2007) tidak meragukan bahwa membaca merupakan kunci keberhasilan seorang siswa. Baginya membaca merupakan faktor penting dalam segala usaha pembelajaran.

Kemampuan membaca yang baik dan benar sangat penting peranananya dalam membantu anak mempelajari berbagai hal (Sudiana, 2007). Melalui aktivitas mambaca yang baik dan benar, anak akan mampu mengambil intisari dari bahan yang dibacanya. Dengan demikian anak bisa mendapatkan sesuatu dari aktifitas membaca yang dilakukannya. Semakin besar intisari yang bisa dipahami dari isi bacaan semakin banyak pula pengetahuan yang diperoleh. Banyaknya pengetahuan ini akan sangat membantu anak dalam menjalani kehidupanya di masa depan. Selain itu, kemampuan nalar anak akan berkembang dengan pesat ketika anak berhasil mendapat informasi melalui bahan bacaan. Demikian betapa pentingnya membaca bagi kehidupan sehari-hari, dengan membaca dapat dibuka cakrawala ilmu pengetahuan, teknologi, dan seni serta wawasan tentang dunia luar yang menyimpan sejuta misteri. Selain itu informasi yang berkembang sangat pesat bisa diperoleh melalui membaca (Harjasujana dan Mulyati, 1996).

Kemampuan membaca bukanlah kemampuan yang diwariskan secara turun menurun, walaupun pada dasarnya manusia memiliki kemampuan secara alamiah. Manusia mampu membaca jika berlatih. Namun membaca secara intensif memerlukan pelatihan dan pengarahan atau pembimbingan yang khusus. Karena membaca intensif merupakan membaca secara cermat untuk memahami suatu teks atau isi bacaan secara tepat dan akurat (Arini, 2006).

Untuk meningkatkan kemampuan membaca, maka perlu adanya upaya perbaikan terhadap proses pembelajaran. Proses pembelajaran yang baik hendaknya dapat menumbuhkan minat, motivasi, dan aktivitas belajar. Untuk menciptakan pembelajaran seperti itu, guru harus kreatif baik dalam pemilihan strategi pembelajaran, media pembelajaran, maupun dalam menciptakan suasana yang kondusif di dalam kelas pada saat proses pembelajaran agar dapat menarik minat siswa dalam pembelajaran membaca (Abimanyu, 2008).

Selama ini, proses pembelajaran Bahasa Indonesia khususnya dalam aspek membaca di SD No. 4 Penarukan masih berpusat pada guru. Berdasarkan hasil observasi dan wawancara dengan Ketut Marniati, S.Pd.SD. (guru bidang studi Bahasa Indonesia kelas IV SD No. 4 Penarukan) metode yang digunakan dalam pembelajaran lebih banyak menggunakan metode ceramah disertai tanya jawab dan diskusi. Walaupun telah menerapkan metode diskusi, namun diskusi yang dilakukan kurang terstruktur sehingga dalam proses pembelajaran menemui banyak kendala. Kendala-kendala yang dialami yaitu konsentrasi siswa ketika mengikuti proses pembelajaran tidak bertahan lama, mereka cenderung sibuk sendiri, saat berdiskusi siswa cendrung bercanda ataupun ngobrol dengan temannya, serta ketika guru menjelaskan materi pelajaran, siswa cepat merasa bosan, dan motivasi untuk belajar rendah. Hal ini berdampak pada kemampuan siswa dalam membaca dan memahami isi bacaan, siswa hanya sekedar membaca tanpa dapat memahami isi teks bacaan secara mendalam. Akibatnya, sekitar 50\% siswa kelas IV memperoleh nilai pada mata pelajaran Bahasa Indonesia khususnya dalam aspek membaca di bawah kriteria ketuntasan minimal (KKM). Kreteria ketuntasan minimal untuk aspek membaca yang ditetapkan sekolah adalah 62 .

Jika kendala-kendala dalam pembelajaran seperti di atas terus dibiarkan begitu saja, maka sudah tentu tujuan pembelajaran yang ditetapkan tidak akan tercapai secara optimal. Disamping itu, jika kemampuan siswa dalam membaca dan memahami teks bacaan masih rendah akan berimbas pada pencapaian kompetensi siswa pada mata pelajaran yang lain. Hal ini disebabkan karena kemampuan membaca merupakan salah satu kemampuan dasar yang dapat menunjang pencapaian kompetensi siswa dalam berbagai mata pelajaran.

Berdasarkan uraian tersebut, pengelolaan proses pembelajaran memegang peranan sangat penting guna mengaktifkan pembelajaran dan mencapai tujuan pembelajaran yang optimal. Salah satu pengelolaan proses pembelajaran dapat dilakukan melalui penerapan strategi pembelajaran secara tepat. Strategi pembelajaran dikatakan memegang peranan penting karena strategi pembelajaran menunjuk kepada pengaturan (memilih, menyusun dan memobilisasi) cara, sarana/prasarana dan tenaga untuk mencapai tujuan pembelajaran (Sudijarto dalam Abimanyu, 2008). Namun, penerapan strategi pembelajaran harus memperhatikan karakteristik peserta didik dan kesesuaiannya dengan materi pelajaran (Sanjaya, 2008).

Mengingat pentingnya peranan strategi pembelajaran, maka ditawarkan salah satu upaya untuk mengatasi permasalahan yang telah diuraikan di atas yakni dengan penerapan strategi pembelajaran Think Pair Share (TPS). Penerapan strategi pembelajaran Think Pair Share (TPS) dapat mengembangkan kecakapan hidup sosial siswa. Strategi pembelajaran ini membuat siswa memiliki ketergantungan positif dengan teman satu kelompok, saling berbagi ide, mempunyai kesempatan yang sama dalam berpartisipasi 
dan lebih meningkatkan banyaknya informasi untuk diingat. Strategi pembelajaran Think Pair Share memberikan waktu kepada siswa untuk berpikir dan merespon serta saling bantu satu sama lain. Dengan Think diharapkan siswa bisa membaca dan memikirkan sendiri isi atau pokok bahasan dari bacaan tersebut, Pair siswa mendiskusikan hasil pemikirannya dengan seorang mitra, dan Share siswa berbagi hasil diskusinya pada tahap pairing dengan seluruh siswa satu kelas. Berdasarkan latar belakang di atas, dilakukan penelitian yang berjudul "Penerapan Strategi Pembelajaran Think Pair Share (TPS) untuk Meningkatkan Kemampuan Membaca Intensif Siswa Kelas IV Semester II Tahun Ajaran 2010/2011 pada SD No. 4 Penarukan".

\section{Metode}

Penelitian tindakan kelas ini akan dilaksanakan di SD No. 4 Penarukan. Dalam penelitian ini, peneliti berkolaborasi dengan guru pengajar Bahasa Indonesia di kelas IV. Pada penelitian ini yang menjadi subjek penelitian adalah siswa kelas IV yang berjumlah 28 orang, yang terdiri dari 16 orang siswa laki-laki dan 12 orang siswa perempuan. Sedangkan yang menjadi objek penelitian adalah kemampuan membaca intensif dan penerapan strategi pembelajaran Think Pair Share.

Penelitian ini menggunakan rancangan penelitian tindakan kelas (PTK) atau classroom action research. Dikatakan demikian karena penelitian ini akan dilaksanakan di dalam kelas dengan menerapkan tindakan yang disengaja dalam upaya perbaikan terhadap proses pembelajaran. Ini sesuai dengan pengertian penelitian tindakan kelas, yang diungkapkan oleh Wendra (2009) bahwa "penelitian tindakan kelas merupakan penelitian yang dilakukan di kelas dengan melakukan kegiatan tertentu dalam rangka memecahkan masalah yang sedang dihadapi oleh guru dalam pembelajaran".

Penelitian ini dilaksanakan sebagai upaya perbaikan dan pengembangan pelaksanaan pembelajaran di kelas karena masih banyak problematika pembelajaran yang menghambat kemajuan pendidikan saat ini. Hal tersebut tercermin pada masih kurangnya kemampuan siswa dalam membaca intensif. Dengan demikian, penelitian tindakan kelas (PTK) adalah penelitian yang bersifat aplikasi (terapan), terbatas, segera, dan hasilnya untuk memperbaiki dan menyempurnakan program pembelajaran yang sedang berjalan. Tindakan yang dilakukan mulai dari menelaah, mendiagnosis penyebab-penyebab permasalahan tersebut dan mencarikan solusi untuk mengatasi masalah tersebut. Pada penelitian ini diterapkan strategi pembelajaran Think Pair Share dalam upaya meningkatkan kemampuan membaca intensif siswa kelas IV SD No. 4 Penarukan. Pemberian tindakan dalam penelitian ini dilakukan melalui dua siklus. Setiap siklus terdiri atas empat tahapan yaitu tahap perencanaan, tahap pelaksanaan tindakan, tahap observasi/evaluasi, dan tahap refleksi

Adapun metode pengumpulan data yang akan digunakan dalam penelitian ini adalah dengan menggunakan Metode Tes.Tes biasanya diberikan pada setiap akhir kegiatan pembelajaran. Menurut Poerwanti (2008) Tes diartikan "sebagai himpunan pertanyaan yang harus dijawab, pernyataanpernyataan yang harus dipilih/ditanggapi, atau tugas-tugas yang harus dilakukan oleh peserta tes dengan tujuan untuk mengukur suatu aspek tertentu dari peserta tes". Sedangkan Nurkancana dan Sunartana (1990) mengungkapkan bahwa tes adalah suatu cara untuk mengadakan penilaian yang berbentuk suatu tugas yang dikerjakan oleh anak atau sekelompok anak sehingga menghasilkan suatu nilai tentang tingkah laku atau prestasi anak tersebut, yang dapat dibandingkan dengan nilai yang dicapai oleh anak-anak lain atau dengan nilai standar yang ditetapkan. Tes dalam penelitian ini digunakan untuk mengukur kemampuan membaca intensif siswa kelas IV adalah butir butir tes yang sesuai dengan teks bacaan yang diberikan yang berupa tes pilihan ganda, dan untuk penskoran hasil tes menggunakan panduan evaluasi yang memuat kunci jawaban dan pedoman penskoran setiap butir soal.Metode pemberian tes yang digunakan mengacu pada Taksonomi Bloom seperti diungkapkan Harjasujana dan Mulyati (1996) untuk mengetahui atau mengukur kemampuan membaca intensif siswa setelah penerapan strategi pembelajaran Think Pair Share.

Analisis data tentang kemampuan membaca intensif dalam mata pelajaran bahasa Indonesia siswa kelas IV SD No. 4 Penarukan menggunakan metode analisis deskriptif kuantitatif yaitu suatu cara pengolahan data yang dilakukan dengan jalan menyusun secara sistematis dalam bentuk angka-angka dan persentase mengenai suatu objek yang diteliti, sehingga diperoleh kesimpulan umum. Metode analisis data ini digunakan untuk menganalisis data kemampuan membaca intensif siswa.

Dalam penelitian tindakan kelas ini cara pengolahan data yang digunakan dibatasi pada menggunakan distribusi frekuensi, angka rata-rata (mean), rata-rata persentase tingkat kemampuan membaca intensif siswa dan penentuan tingkat kemampuan membaca intensif siswa. 


\section{Hasil Dan Pembahasan}

\section{Hasil}

Pada tahap refleksi awal, mencari data nilai ulangan harian terakhir Bahasa Indonesia pada aspek membaca khususnya dalam membaca intensif siswa kelas IV SD No. 4 Penarukan berdasarkan dokumen daftar nilai dari guru Bahasa Indonesia kelas IV. Pencarian nilai ini dimaksudkan untuk mengetahui keterampilan siswa dalam aspek membaca khususnya dalam membaca intensif sebelum tindakan dan sebagai skor awal. Selain itu, data skor pada refleksi awal juga digunakan untuk mengetahui skor kemajuan individu. Data ini digunakan untuk lebih menguatkan hasil observasi dan wawancara yang telah dilakukan, bahwa di kelas tersebut hasil belajar Bahasa Indonesia dalam aspek membaca khususnya membaca intensif siswanya masih cukup rendah. Rata-rata presentase hasil belajar Bahasa Indonesia dalam aspek membaca khususnya membaca intensif siswa hanya 59,29\% dan berada pada katagori kurang, selain itu terdapat dari sekitar 50\% hasil belajar siswa di bawah KKM, yaitu di bawah 62 .

Pada siklus I yang dilaksanakan diperoleh hasil sebagai berikut: 1) Dalam setiap kali pertemuan selama siklus I, rata-rata hanya 12 orang siswa yang tampak aktif dan antusias selama proses pembelajaran. Sedangkan siswa yang lain tampak kurang aktif dan kurang antusias. 2) Dalam diskusi kelompok siswa rata- rata hanya 7 kelompok yang bekerja secara sungguh-sungguh sedangkan siswa yang lain ada yang hanya mencontek pekerjaan temannya bahkan ada yang bermain-main saat diskusi kelompok. 3) Interaksi siswa dalam diskusi kelas terutama saat penyajian hasil kerja masih tampak rendah. Rata-rata hanya 4 orang yang berani memberi tanggapan atas jawaban temannya dan mau bertanya atau mengemukakan pendapatnya. Hasil tes akhir siklus I dapat dilihat pada tabel 1 Berdasarkan data tersebut diketahui bahwa jumlah seluruh siswa yang mengikuti tes (N) 28 orang. Rincian skor yang diperoleh siswa antara lain,

\begin{tabular}{ccc}
\multicolumn{4}{c}{ Tabel 1 Data Distribusi Frekuensi Siklus I } \\
\hline $\mathrm{X}$ & $\mathrm{F}$ & $\mathrm{fX}$ \\
\hline 85 & 1 & 85 \\
80 & 1 & 80 \\
75 & 3 & 225 \\
70 & 4 & 280 \\
65 & 14 & 910 \\
50 & 2 & 100 \\
45 & 3 & 135 \\
\hline$\Sigma$ & 28 & 1815 \\
\hline
\end{tabular}

Berdasarkan data tersebut kemampuan membaca intensif siswa kelas IV SD No. 4 Penarukan pada siklus pertama tergolong kurang dan masih terdapat 5 orang siswa yang belum mencapai nilai ketuntasan minimal yang ditetapkan sekolah.

Kegiatan pembelajaran pada siklus I sudah berlangsung cukup baik, tetapi belum optimal. Meskipun demikian, ditemukan beberapa permasalahan dalam proses pembelajaran yang perlu dijadikan refleksi untuk perbaikan pada siklus selanjutnya. Secara umum permasalahan yang muncul dapat dijabarkan sebagai berikut. 1) Keaktifan siswa dalam menanggapi pertanyaan dari guru masih kurang optimal, terutama pada pertemuan-pertemuan awal. Siswa masih ragu-ragu dalam mengajukan pendapat atau gagasannya. Mereka masih takut jika jawaban yang disampaikan salah. Cara yang akan dilakukan peneliti bersama guru untuk meminimalisasi permasalahan ini pada siklus berikutnya adalah dengan memberikan motivasi, penguatan berupa pujian bagi siswa yang sudah berani menjawab atau memberikan pendapat. Selain itu, peneliti bersama guru juga berusaha menjelaskan bahwa jawaban atau pendapat yang disampaikan siswa tidak akan pernah disalahkan. Dengan demikian siswa diharapkan lebih berani menjawab pertanyaan-pertanyaan guru, menyampaikan gagasan atau pendapatnya. 2) Pada saat pembagian kelompok kebanyakan siswa tidak setuju dipasangankan dengan teman sebangkunya, sehingga suasana menjidi ricuh dan waktu lebih lama terlewatkan untuk memasangkan siswa. Upaya yang akan dilakukan guna memperbaiki hal tersebut pada siklus selanjutnya adalah mengatur komposisi kelompok secara heterogen. Karena kebanyakan siswa duduk dengan tingkan kemampuan yang homogen. 3) Kegiatan diskusi kelompok dan diskusi kelas belum sepenuhnya efektif, dalam hal ini siswa kurang aktif dalam mengemukakan pendapat dan hanya mengandalkan pendapat teman yang pintar dari kelompoknya. Ada beberapa siswa yang hanya diam menunggu jawaban teman dalam kelompoknya tanpa menghiraukan kebenaran dari jawaban tersebut. Upaya yang akan dilakukan guna memperbaiki hal tersebut pada siklus berikutnya adalah dengan memberikan pertanyaan atau pernyataan yang dapat dijadikan acuan oleh siswa dalam memberikan pendapatnya. Dengan melakukan upaya seperti itu 
diharapkan dapat memberikan motivasi yang positif kepada siswa. 4) Masih banyak siswa yang mengalami kesulitan dalam menemukan kalimat utama dalam setiap paragraf. Upaya yang akan dilakukan guna memperbaiki hal tersebut pada siklus berikutnya adalah lebih memberikan bimbingan dan penekanan saat diskusi kelompok maupun penyimpulan tentang ciri kalimat utama dan kalimat penjelas. 5) Waktu masih merupakan kendala utama. Banyak waktu terbuang hanya untuk membentuk kelompok, serta ketidak disiplinan siswa memanfaatkan waktu pada tahap Thinking maupun pada tahap Pairing. Upaya yang akan dilakukan guna memperbaiki hal tersebut pada siklus berikutnya adalah mempertegas waktu yang disediakan pada setiap tahapan.

Berdasarkan hasil observasi yang dilaksanakan setiap kali pembelajaran berlangsung, dapat dirangkum beberapa hal sebagai berikut. 1) Dalam setiap kali pertemuan selama siklus II, rata-rata sudah hampir 20 orang siswa yang tampak aktif dan antusias selama proses pembelajaran serta berusaha menyampaikan gagasan-gagasan atau pendapat-pendapat yang mereka miliki. 2) Dalam diskusi kelompok, rata-rata sebanyak 12 kelompok sudah dapat bekerja sama secara sungguh-sungguh serta dapat memberikan pendapat tentang permasalahan yang berkaitan dengan isi teks bacaan yang diberikan. 3) Interaksi siswa dalam diskusi kelas terutama saat penyajian hasil kerja sudah jauh lebih meningkat dibandingkan pada siklus I. Rata-rata sudah hampir 20 orang yang berani memberi tanggapan atas jawaban temannya dan mau bertanya atau mengemukakan pendapatnya.

Hasil tes akhir siklus II dapat dilihat pada lampiran 2. Berdasarkan data tersebut diketahui bahwa jumlah seluruh siswa yang mengikuti tes (N) 28 orang. Rincian skor yang diperoleh siswa antara lain

\begin{tabular}{ccc} 
Tabel 2 Tabel Data Distribusi Frekuensi Siklus \\
\hline $\mathrm{X}$ & $\mathrm{f}$ & $\mathrm{fX}$ \\
\hline 100 & 2 & 200 \\
95 & 1 & 95 \\
85 & 4 & 340 \\
80 & 3 & 240 \\
75 & 8 & 600 \\
70 & 7 & 490 \\
65 & 3 & 195 \\
\hline$\sum$ & 28 & 2160 \\
\hline
\end{tabular}

Berdasarkan data tersebut persentase tingkat kemampuan membaca intensif siswa kelas IV SD No. 4 Penarukan pada siklus II sebesar $77,14 \%$ dan tergolong pada kategori cukup serta kreteria keberhasilan pada penelitian ini sudah tercapai. Sehingga penelitian dianggap sudah berhasil dan pemberian tindakan dapat dihentikan.

Kegiatan pembelajaran pada siklus II secara umum sudah berjalan dengan baik dan tampak sudah ada peningkatan, baik dari segi proses maupun hasil tindakan. Bimbingan yang dilakukan guru membuat siswa lebih berani menjawab pertanyaan yang diajukan dan mengemukakan pendapatnya. Adanya rasa kesadaran untuk menghargai setiap pendapat juga dapat memotivasi siswa untuk lebih leluasa mengemukakan pendapat, meskipun apa yang disampaikan masih belum tepat. Hal tersebut dapat melatih siswa untuk menyampaikan gagasan-gagasan yang dimiliki.

Adapun temuan-temuan yang diperoleh selama pelaksanaan tindakan siklus II adalah sebagai berikut. 1) Kegiatan pembelajaran pada setiap pertemuan dalam siklus II menunjukkan situasi belajar yang lebih kondusif, jika dibandingkan dengan pertemuan-pertemuan sebelumnya pada siklus I. Siswa sudah mulai terbiasa dengan penerapan pembelajaran yang menuntut aktivitas tinggi. 2) Selama proses pembelajaran, semakin banyak siswa yang meningkat aktivitas belajarnya, seperti antusiasme, keaktifan dan interaksi siswa. Siswa semakin terbiasa belajar dengan diberi permasalahan dan berdiskusi dalam kelompok untuk menemukan pemecahan masalah. 3) Hasil tes akhir siklus II, menunjukkan peningkatan terhadap kualitas jawaban yang dibuat siswa dalam setiap butir soal.

Hasil dari refleksi ini menunjukkan bahwa dengan perbaikan yang dilakukan terjadi peningkatan kualitas dari segi kegiatan proses belajar mengajar di kelas dan hasil belajar siswa.

Untuk dapat mengetahui keberhasilan penelitian diperlukan adanya perbandingan nilai kemampuan membaca intensif siswa antara refleksi awal dengan siklus I, dan dengan siklus II. Hasil perbandingan tersebut dapat dilihat seperti yang termuat pada tabel 3 di bawah ini. 
Tabel 3. Perbandingan Data Kemampuan Membaca Intensif Siswa

\begin{tabular}{ccc}
\hline \multirow{2}{*}{ Tahapan } & $\begin{array}{c}\text { Rata-rata Persentase Skor Kemampuan Membaca } \\
\text { Intensif Siswa }\end{array}$ & \multirow{2}{*}{ Kategori } \\
\hline Refleksi Awal & $59,29 \%$ & Kurang \\
Siklus I & $64,82 \%$ & Kurang \\
Siklus II & $77,14 \%$ & Cukup \\
\hline
\end{tabular}

Berdasarkan gambar 3 di atas, terlihat bahwa rata-rata persentase kemampuan membaca intensif siswa mengalami peningkatan yaitu dari 59,29\% pada refleksi awal (sebelum pelaksanaan tindakan) menjadi $64,82 \%$ pada siklus I, dan menjadi $77,14 \%$ pada siklus II. Dari hasil tersebut dapat disimpulkan bahwa penerapan strategi pembelajaran think pair share dapat meningkatkan kemampuan membaca intensif siswa kelas IV SD No. 4 Penarukan pada tahun pelajaran 2010/2011.

\section{Pembahasan}

Berdasarkan hasil evaluasi kemampuan membaca intensif sebelum dilaksanakan tindakan (refleksi awal), siklus I, dan siklus II, ketiga hasil kegiatan evaluasi itu menampakan terjadinya peningkatan kemampuan membaca intensif meskipun tidak terlalu tinggi. Peningkatan itu terjadi terjadi karena penerapan strategi pembelajaran think pair share.

Berdasarkan temuan dan hasil analisis data pada siklus I menunjukan peningkatan kemampuan membaca intensif siswa. Peningkatan ini terjadi dikarenakan dalam proses pembelajaran guru menerapkan suatu strategi pembelajaran yang tepat yaitu penerapan strategi pembelajaran think pair share. Dengan penerapan strategi pembelajaran ini proses pembelajaran tidak lagi berpusat pada guru, keterlibatan siswa dalam proses pembelajaran sudah nampak. Keterlibatan siswa secara tidak langsung akan membuat siswa memperoleh dan menggali pengetahuan sendiri yang nantinya dapat dikembangangkan lebih lanjut. Hal ini sejalan dengan yang dikemukakan oleh Lie (2002) yang menyatakan bahwa guru harus menciptakan kondisi dan situasi yang memungkinkan siswa untuk menemukan dan membentuk makna dari bahan-bahan pelajaran melalui suatu proses belajar, kemudian menyimpan dalam ingatan yang sewaktu-waktu dapat diproses dan dikembangkan.

Walapun kemampuan membaca intensif siswa pada siklus I ini sudah mengalami peningkatan, namun belum mencapai kreteria keberhasilan yang telah ditargetkan. Hal ini terjadi karena dalam penerapan strategi pembelajaran think pair share belum dilaksanakan secara efektif. Maka dari itu, pada siklus II dilakukan penyempurnaan dan perbaikan lagi, agar nantinya dapat meningakatkan kemampuan membaca intensif siswa.

Hasil analisis data pada siklus II menunjukan kemampuan membaca intensif siswa semakin meningkat serta rata-rata persentase kemampuan siswa sudah melampaui target yang telah ditetapkan. Peningkatan ini disebabkan karena strategi pembelajaran think pair share sudah dilaksanakan secara efektif. Penerapan strategi pembelajaran think pair share secara efektif memberikan siswa lebih banyak waktu untuk berpikir, menjawab, dan saling bantu satu dengan yang lain. Siswa diberikan lebih banyak waktu untuk berpikir secara individu dikarenakan berpikir secara individu merupakan salah satu aktivitas untuk memberikan tanggung jawab pada masing-masing siswa. Penerapan strategi pembelajaran think pair share membantu siswa berpikir dan berbuat secara benar dengan membiarkannya berpikir sendiri. Berpikir yang baik lebih penting daripada sekadar memiliki jawaban yang benar terhadap suatu persoalan. Jika siswa memiliki cara berpikir yang baik, maka cara berpikir tersebut dapat digunakan dalam mengkaji dan menemukan solusi dari permasalahan yang dibahas. Sementara itu, siswa yang sekadar menemukan jawaban yang benar dari permasalahan yang diajukan guru belum tentu dapat memecahkan persoalan baru, karena mereka tidak memahami dengan benar bagaimana menemukan jawaban tersebut. Hal ini sejalan dengan temuan penelitian Solan (dalam Pujawan 2008), yang menyatakan pemahaman siswa akan meningkat secara menyakinkan bila mereka diberi waktu secukupnya untuk berpikir.

Dengan penerapan pembelajaran yang mengunakan strategi think pair share, selain diberikan lebih banyak waktu untuk berpikir secara individu, siswa juga berdiskusi dengan siswa yang lain secara berkelompok/berpasangan. Melalui diskusi ini, siswa dilatih untuk belajar mengungkapkan dan menerima ide yang telah dipikirkan pada tahap thinking untuk menyamakan persepsi sampai tercapai satu kesepakatan tentang solusi dari permasalahan yang dibahas. Diskusi dapat lebih mengembangkan kecakapan hidup sosial siswa. Dengan menerapkan diskusi dalam kelompok dalam pembelajaran, siswa dirangsang untuk mengembangkan kemampuan berpikir dan berkomunikasi. Buah pemikiran mereka akan dihargai sehingga siswa semakin terdorong untuk belajar serta memberikan kebermaknaan dalam proses pembelajaran sehingga materi pembelajaran akan dengan mudah dipahami dan sulit untuk dilupakan. Selain itu, siswa yang belajar dan bekerja sama dengan sesama teman dalam suasana kelompok 
akan mempunyai banyak kesempatan untuk mengolah informasi dan meningkatkan keterampilan berkomuikasi (Lie, 2002). Hal senada juga diungkap Ibrahim (2000), "siswa memiliki kemungkinan menggunakan tingkat berpikir yang lebih tinggi selama dan setelah diskusi dalam kelompok dari pada mereka bekerja secara individu atau kompetitif. Jadi materi yang dipelajari siswa akan melekat untuk periode waktu yang lebih lama."

Dalam proses pembelajaran ini, siswa yang telah melakukan diskusi dengan pasangan atau kelompoknya, berbagi atau sharing dengan seluruh teman di kelas. Sharing dengan teman memberi kesempatan pada siswa untuk mengungkapkan gagasan, mendengar pendapat teman serta secara bersama-sama membangun pengertian, dan menjadi sangat penting dalam pembelajaran, hal ini dapat menumbuhkan pemahaman siswa dan kemampuan berkomunikasi siswa yang berujung pada peningkatan kemampuan membaca intensif siswa. Hal tersebut sejalan dengan pendapat Pujawan (2008) yakni, "belajar untuk menjelaskan, mendengarkan dan menilai pendapat orang lain serta mengomentari gagasan orang lain merupakan kesempatan untuk meningkatkan pemahaman mereka terhadap masalah yang dibahas ".

Berdasarkan peningkatan kemampuan membaca intensif siswa dari repleksi awal kemudian pada siklus I dan siklus II, penelitian tindakan kelas yang dilaksanakan di SD No. 4 Penarukan melalui penerapan strategi pembelajaran think pair share ternyata mampu memberikan perubahan yang lebih baik terhadap kemampuan membaca intensif siswa. Di samping itu juga dapat mengubah situasi belajar siswa yang tadinya fakum dikarenakan pembelajaran masih berpusat pada guru namun setelah diterapkan strategi pembelajaran think pair share siswa lebih leluasa untuk belajar dengan dapat memikirkan permasalahan yang dibahas secara mandiri, mendiskusikan pemikirannya dengan seorang teman, dan berbagi dengan seluruh kelas. Hal ini akan menumbuhkan kebermaknaan dalam proses pembelajaran, materi pelajaran akan mudah untuk diserap dan sulit untuk dilupakan. Hal senada juga diungkapan oleh Pujawan (2008), "melalui penerapan strategi pembelajaran Think Pair Share, siswa akan merasa betul-betul terlibat dalam pembelajaran, dan keterlibatan ini akan membuat siswa senang belajar dan menghargai pelajaran sehingga berujung pada pemahaman siswa dalam memahami materi pelajaran"

\section{Simpulan Dan Saran}

Berdasarkan hasil penelitian dan pembahasan yang telah diuraikan, dapat disimpulkan bahwa penerapan strategi pembelajaran Think Pair Share dapat meningkatkan kemampuan membaca intensif siswa kelas IV semester II SD Negeri 4 Penarukan. Hal ini dapat dilihat dari semakin meningkatnya kemampuan membaca intensif siswa. Pada refleksi awal rata-rata persentase kemampuan membaca intensif siswa hanya mencapai 59,29\% dan berada pada katagori kurang, meningkat pada siklus I menjadi $64,82 \%$ dan berada pada katagori kurang. Setelah dilaksanakan perbaikan tindakan pada siklus II, ratarata kemampuan membaca intensif siswa semangkin meningkat mencapai $77,14 \%$ dan berada pada kategori cukup.

Mengacu kepada temuan penelitian ini, dapat dikemukakan beberapa saran sebagai berikut. 1) Guru diharapkan dapat menerapakan strategi pembelajaran think pair share sebagai salah satu alternatif untuk mencapai hasil belajar yang optimal dengan tetap memperhatikan karakteristik peserta didik. 2) Kepada pembaca yang berminat untuk mengadakan penelitian lebih lanjut mengenai penerapan strategi pembelajaran Think Pair Share pada pada bidang ilmu Bahasa Indonesia ataupun pada bidang ilmu yang lain, agar memperhatikan segala kendala ataupun kekurangan-kekurangan sebagai bahan pertimbangan untuk menyempurnakan pelaksanaan penelitian.

\section{Daftar Pustaka}

Abimanyu, Soli, dkk. (2008). Strategi Pembelajaran. Jakarta: Depertemen Pendidikan Nasional.

Agung, A. A. Gede. (2005). Metodelogi Penelitian Pendidikan. Singaraja: IKIP Negeri Singaraja.

(2010). "Penelitian Tindakan Kelas ( Teori dan Analisis data dalam PTK)”. Makalah disajikan dalam Workshop Jurusan Pendidikan Guru Sekolah Dasar. FIP Undiksha, Singaraja 27 September 2010.

Arini, Ni Wayan, dkk. (2006). Peningkatan Keterampilan Berbahasa Indonesia Berbasis Kopetensi. Singaraja: Undiksha.

Bahri, S. Djamarah dan Aswan Zain. (2006). Strategi Belajar Mengajar. Jakarta: Rineka Cipta.

Departemen Pendidikan Nasional. (2006). Kurikulum Tingkat Satuan Pendidikan Tentang Standar Kompetensi Mata Pelajaran Bahasa Indonesia di Sekolah Dasar. Jakarta:Depdiknas. 
Harjasujana, A. S. dan Yeti Muyani. (1996). Membaca 2. Jakarta: Departemen Pendidikan dan Kebudayaan. Ibrahim, Muslimin, dkk. (2001). Pembelajaran Kooperatif. Surabaya: Unesa University Press.

Lie, Anita. (2002). Mempraktikkan Cooperatif Learning di Ruang-Ruang Kelas. Jakarta: PT Gramedia.

Moedjiono dan M. Dimiyanti. (1994). Belajar dan Pembelajaran. Jakarta: Depdikbud.

Nurkancana dan Sunartana. (1990). Evaluasi pendidikan. Surabaya: Usaha Nasional.

Poerwanti, Endang dkk. (2008). Asesmen Pembelajaran SD. Jakarta: Depdiknas.

Pujawan, I Gusti Ngurah dkk. (2008). Implementasi Siklus ACE melalui Strategi Pembelajaran Think-PairShare dalam Meningkatkan Kualitas Perkuliahan Geometri Transformasi. Laporan Penelitian (tidak diterbitkan). Singaraja: Undiksha.

Sanjaya, Wina. (2008). Srategi Pembelajaran Berorientasi Standar Proses Pembelajaran. Jakarta: Kencana.

Sudiana, Nyoman. (2007). Membaca. Malang: IKIP Malang.

Sudjana, Nana dan Ahmad Rivai. (1991). Media Pengajaran. Bandung: CV Sinar Baru.

Syafi'ie, Iman. (1993). Materi Pokok Bahasa Indonesia I. Jakarta: Departemen Pendidikan dan Kebudayaan.

Syukri, M. (2008). Penelitian Tindakan Kelas. Jakarta: Diretorat Pendidikan Tinggi Departemen Pendidikan Nasional.

Tarigan, Henry Guntur. (1979). Membaca sebagai Suatu Keterampilan Berbahasa. Bandung: Angkasa.

Trianto. 2010. Mendesain Model Pembelajaran Inovatif-Progresif: Konsep, Landasan dan Implementasinya pada Kurikulum Tingkat Satuan Pendidikan (KTSP). Jakarta: Kencana.

Wendra, I Wayan. (2009). Penulisan Karya Ilmiah. Singaraja: Undiksha 